\title{
Development of Sharing Economy in the Context of Digitalization of Joint Consumption
}

\author{
Tatiana Ignatova ${ }^{1, *}$ Elena Platonova $^{2}$ Antonina Pavlyukova ${ }^{3}$ Grzegorz Sroslak ${ }^{4}$
}

\author{
${ }^{1}$ Russian Presidential Academy of National Economy and Public Administration, South-Russian Institute of \\ management, Rostov-na-Donu, 344002, Russia \\ ${ }^{2}$ Moscow Pedagogical State University, Moscow, 117000, Russia \\ ${ }^{3}$ Moscow State University of Technology and Management by the name of K.G.Razumovskiy (First Cossack University), \\ Rostov-na-Donu, 344002, Russia \\ ${ }^{4}$ Jagiellonian University, Institute of Entrepreneurship, Crakow, 30024, Poland \\ *Corresponding author. Email: tignatova1965@gmail.com
}

\begin{abstract}
The article reveals the importance of a new digital economy for the creation of economy of joint consumption. The authors characterize economy of joint consumption as rather new type of service which technology of providing users (consumers) to a wide range is based on digitalization, development of technological frameworks and online services and follow the evolution of the concept of sharing in studies of modern researchers published in recognized journals. As a result of study authors allocate two stages of development of the concept of sharing economy in last twenty years.

Keywords: concept of sharing, economy of joint consumption, digital economy, online services, technological
\end{abstract}

framework, conceptual development

\section{INTRODUCTION}

In the middle of the 20th century the most known theoretical constructions, reflected a role of scientific and technical progress in life of society, concepts of postindustrial economy (D. Bell, E. Toffler, A. Touraine, etc.), information economy (F. Makhlup, T. Umesao, M. Kastels, V.A. Trapeznikov, etc.), economies of knowledge (P. Druker, M. Porter, etc.), service economy acted (V.R. Fuchs, Zh. Attali, etc.). In spite of the fact that names of a certain state of the economy, it is necessary to carry, in our opinion, to conceptual metaphors, each of these concepts reflects new lines of certain stages of technical and economic progress of society like consolidation [1] or reproduction of resources [2].

In recent years as a powerful trend in a research of patterns of modern economy studying of a phenomenon of digitalization and its influence on all spheres of reproduction of social and economic life of modern society acts. From a position of technical and technological aspects of development of economy the statement that now the mankind lives during an era of digital economy which was created on a new wave of a scientific and technological revolution and mass penetration of its results into services sector is fair.

In the center of attention of economic science there were always questions of definition of characteristics of an economic system and search of patterns of its movement. Many researchers, building these or those theoretical constructs, economies were based on the vision of the main characteristics modern it and selected, first of all, its technical characteristics. It allowed not only to see perspectives of economic development, but also to explain the maintenance of the previous stages of evolution of economy.

Recognition of multi-vector nature of impact of digitalization on services sector updates a task of the analysis of research positions of modern economists on questions of maintenance of rather new concept economy of joint consumption - sharing economy.

\section{BACKGROUND}

\subsection{Genesis of Theory and Methodology of Sharing}

The perspective of joint consumption is not essentially new to economic science. The conceptual ideas about development of the cooperation relations which are the cornerstone of modern economy of joint consumption were developed in works of classics of political economy (A. Smith, T. Malthus, John S. Mill). A certain contribution to development of the theory of consumer cooperation was made by works U. King, L. Blanc, F. Lassal and also Russian economists M.I. TuganBaranovsky, I.V. Yemelyanov, A.V. Chayanov, A.D. Bilimovich and others. In these works they raised important social, economic, technical and technological aspects of development of consumer cooperation which reflected the level of productive forces and relations of production of capitalism of those of years. However the 
value of the ideas of theorists and practitioners of the cooperative movement consists that they considered the sphere of consumption from a position of socialization and efficiency of collective forms of the organization of consumption.

In the 50th years of the 20th century American sociologists actively developed the theory of ecology of the person, one of provisions of which was development of forms of joint consumption and decrease in technogenic load by restriction of uncontrollable individual and collective consumption of natural resources. In 1978 Markus Felson and Joe Spaeth [3] in the article paid attention to ecological models of the person, including, to the model developed by A. Holey. Authors updated the term "joint consumption" (collaborative consumption) and brought up a question of need of continuation of researches for this direction.

Results of the analysis of modern publications with purpose of establishment of temporary borders of origin and evolution of the theoretical concept of sharing economy reflecting the new relations in the sphere of consumption and deep processes of its socialization under the influence of development of digital technologies are presented in chapter.

In the works authors pay attention that thanks to new digital technologies and activity of the knowledgeintensive companies as which product they act technological platform online new opportunities in consumption of all sectors of society are created and perspectives of overcoming social inequality and disproportions in the field of personal consumption appear. Since 2004 the phrase "sharing economy" - joint economy which comes from English "to share" is fixed in works of the western researchers terminologically - to share. The researchers used this concept for characterizing of such a modern phenomena as the integrated (joint) economy, joint consumption, uberization, economy of joint efforts, collaborative consumption.

Regular researches of this new segment of the sphere of consumption in which the building facts in practice of new reproduction model under the influence of digitalization of such industries of services sector as financial services, communication and information services of the Internet, mobile communication, services online for an unlimited circle of consumers are theoretically generalized beginning in the middle of the first decade of the XX century.

The sign boundary in a research of economy of joint consumption can be considered collective work Rachael Botsman and $\mathrm{Ra}$ Rogers [4] in which scales and perspectives of use of rather new model of consumption developing enviable rates (above the market) thanks to implementation of digital platforms in the field of services are disclosed. Success of service of rent of housing Airbnb, the application for search of fellow travelers of BlaBlaCar [5], service of the order of the Uber taxi, an online auction of eBay and other services of joint consumption reflects the need of millions of people around the world for collective forms of the organization of the sphere of providing things and rendering services.

\subsection{Main theoretical approaches}

In modern approaches to a research of economy of joint consumption it is possible to select several directions, each of which reflects the separate parties and features of functioning of economy of joint consumption:

- firstly, industrial and technical and technological (research of specific segments and technologies of consumption);

- secondly, social and economic (research of transformation of the relations of property);

- thirdly, social-and-ecological (research of impact of joint consumption on ensuring sustainable development and decrease in technogenic load of the nature);

- fourthly, organizational and economic (a research of business models in the field of provision of services of joint consumption and studying of changes of models of joint consumption of things and services);

- fifthly, social and psychological (a research of the culture features which are shown in the field of joint consumption in different national-state models of economy);

- sixthly, institutional (a research of modification of institutes of regulation of the relations of joint consumption, including a research of risks and effects).

Selection of this directions is rather conditional, but it is necessary in the analysis of such difficult and dynamically developing segment of reproduction model of modern economy - economies of joint consumption.

Within the first direction it is reasonable to characterize economy of joint consumption as rather new type of service which technology of providing users (consumers) to a wide range is based on digitalization, development of technological frameworks and online services:

1) car-sharing and a cycle sharing providing shared access to use of privately owned vehicles and bicycles and/or their parking;

2) flat sharing which is understood as the widespread system of providing personal houses, apartments, apartments, dachas generally for tourists for the period of their travel;

3) financial and credit services providing joint financing with households of real estate objects generally for further sharing, including, social objects (collaborative finance) and also peer-to-peer crediting (crowdfunding and peer-topeer lending) directly between natural persons for implementation of some project, socially important for them;

4) transport services on the principles of the Uber company (uberization) allowing to involve nonprofessional drivers for carrying of passengers (the alternative taxi);

5) rendering household services through online services and/or mobile applications (for example, You Do service, etc.);

6) services of purchase and sale of various personal belongings, including cars, without intermediaries and/or their rent (for example, service the Spinning top and so forth).

Despite a variety of the types of service given above in economy of joint consumption, access to their receiving 
from households and a possibility of rendering by their households to wide layers of consumers are mediated by digital technologies and mobile services which develop the hi-tech companies. In 2015 the terms "joint economy" and "sharing" were added to the Oxford dictionary. In the Oxford dictionary a definition of economy of sharing is contained: "An economic system in which assets or services are distributed between individuals or it is free, or for a payment, as a rule, by means of the Internet".

\section{CONCLUSIONS}

Studies of consumption sphere does not act as the new research direction for Russian economic science as problems of interrelation of consumption and accumulation always stood in the center of reproduction models and regularities of modern reproduction. Theoretical and methodological bases of such researches were developed by Russian economists during the transformational period and in the last decade from a position, first of all, of identification of factors of economic growth in the conditions of innovative economy. The concept of sharing economy was formed as a result of processes of digitalization of all spheres of activity of modern society, reflecting high-quality changes in technical characteristics on a way of production and consumption. The term "sharing economy" that came into theoretical economics from modern business language is used as sharing by economic agents of separate types of resources, distribution of economic benefits and reduction of transaction expenses in the sphere of consumption of goods and services.

For justification of the most significant lines of transition to digital economy researchers fairly point to interrelation of digital transformation with a new wave of a scientific and technological revolution which materializes in revolutionary achievements "Industries 4.0", characteristic of the sector of B2B (robotization, big data, the complemented production, 3D printing, cloud computing and data storage, augmented reality and so forth).

However, revolutionary effects of influence of digital technologies on a way of production of goods and services show even the bigger value of patterns of modern economy and profound changes in technologies of personal consumption used by millions of households worldwide.

In the late nineties of the 20th century in the Western economies rapid creation of the knowledge-intensive productions on the principles of economy of knowledge, intensive development of information and communication technologies, the global Internet and the new technological services tied to mobile devices was observed.

In 2002 in Scopus database a publication of Swedish researcher Alexander Stehre [6] appeared in which the author indicates the need for judgments of a role of the knowledge-intensive companies in economy of exchange (sharing economy). The researcher stated the point of view that joint activity in the knowledge-intensive organizations and the subsequent use of its hi-tech products are based on exchange, but not on operation.

Reconsideration by the author of the contents arising under the influence of the changing technological way of the relations in the sphere of mass consumption of hi-tech products which are offered at the market of information and communication technologies, laid the foundation for formation of new conceptual approaches of Western researchers to problems of social equality in economy and democratization of access to achievements of the knowledge-intensive products.

This line is developing in the article of Lorna Gold [7] in which the role of small enterprises in decreasing the poverty by means of providing access for all households to the global Internet is investigated. The author arose a question: whether the global network with participation of business community and the organizations of civil society could offer new approach to restoration of balance between creation of wealth and its distribution in the globalized world.

From 2004 to 2009 titles of publications of modern researchers in Scopus database if being judged by results of their selection by the word "sharing" in relation to formation of the concept of sharing economy, confirm the interest of authors to problems of exchange of information in economy of knowledge and the influence of various factors onto this exchange, in particular, social and cultural factors. At the same time, during this period in economies of the developed and developing states there is a rough formation of models of joint consumption on the basis of development of online technologies and purchases through mobile Internet services. Consumption of higher education services helps to development of innovative thinking of people as managers of their household [8].

Active application by consumers of new technological capabilities on the basis of mass distribution of gadgets and growth of sales of financial, transport, hotel services online confirmed high-quality shifts in behavior of consumers and changes in their preferences in favor of new technologies of shopping for personal consumption. These processes which are dynamically happening in the sphere of consumption with some delay were generalized in publications by marketing specialists and economists that began to appear in Scopus base.

In 2010 there was an article of Chinese author S. Wang about the role of the technological platform of exchange of information in a supply chain of goods and services in the conditions of regional economy with justification of design methods of the platform, modules of demand and their functionality for approach of information to the mass consumer and creations for them convenient services [9]. Same year collective article of the European authors brought up a question of ecological aspects of economy of joint consumption on the example of the analysis of use of eco-friendly cars on hydrogen fuel [10].

Reconsideration of practice of sharing economy contains in work of Lizzie Richardson who writes that the economy of sharing unites around the activity which is carried out by means of the digital platforms providing equal access to goods and services [11]. It represents the obvious paradox 
[3] M. Felson, J.L Spaeth, Community Structure and Collaborative Consumption: A Routine Activity Approach. American Behavioral Scientist, 1978, 21 (4), pp. 614-624.

[4] R. Botsman, R. Rogers What's Mine is Yours: The Rise of Collaborative Consumption (2010). - URL: http://appli6.hec.fr/amo/Public/Files/Docs/241_fr.pdf

[5] F. Bardhi, G.M. Eckhardt Access-based consumption: The case of car sharing. Journal of Consumer Research, 2012,39 (4), pp. 881-898.

6] A. Styhre. The knowledge-intensive company and the economy of sharing: Rethinking utility and knowledge management. Knowledge and Process Management, 2002, 9(4), pp. 228-236.

[7] L. Gold. Small enterprises at the service of the poor: The economy of sharing network. International Journal of Entrepreneurial Behaviour \& Research. 2003. 9(5), pp. 166-184.

[8] T. Ignatova, G. Ovcharenko, N. Larkina, E. Filimontseva Higher education impact onto development of innovative thinking of managers /Revista ESPACIOS. 2019. Vol.40. № 21. P.17. https://revistaespacios.com/a19v40n21/19402117.html

[9] X. Wang. Research on information sharing platform of supply chain under regional economies environment. Proceedings - 3rd International Conference on Information Management, Innovation Management and Industrial Engineering, 2010. pp. 366-369.

[10] A. Kriston, T. Szabó, G. Inzelt. The marriage of car sharing and hydrogen economy: A possible solution to the main problems of urban living. International Journal of Hydrogen Energy, 2010, 35 (23), pp. 12697 12708.

[11] L. Richardson, Performing the sharing economy. Geoforum, 2015, 67, pp. 121-129.
[2] E.D. Platonova, Yu.I. Bogomolova, S.Yu. Krasovsky Economy of resourses: reproduction approach. Monography. Moscow: APKiPPRO, 2013179 p.
[1] T. Ignatova, A. Pavlyukova, L. Boldyreva, S. Solonina Management of consolidation processes in Russia: social and economic aspects. CBU International Conference on Innovations in Science and Education. Prague, Czech Republic, 21-23 March, 2018. Vol. 6, pp. 393-398. 